\title{
Zasady rozbudowywania frazy nominalnej w języku niemieckim i polskim
}

\section{Rules for the extension of nominal phrases in German and Polish}

\author{
Artur Dariusz Kubacki \\ INSTYTUT FILOLOGII GERMAŃSKIEJ, UNIWERSYTET ŚLĄSKI W KATOWICACH \\ UL. GEN. GROTA-ROWECKIEGO 5, 41-205 SOSNOWIEC \\ kubart@post.pl
}

\begin{abstract}
The aim of the article is to present and examine the rules for the extension of nominal phrases in German and Polish. The analysis concerns the patterns of the extension of German and Polish attributes according to Schatte, Jodłowski, Weinrich, and also according to connotation (valency) principles. On the basis of the German deverbative nouns with the suffix -ung found in an arbitrarily selected legal and economic text, the author shows how connotations are inherited.
\end{abstract}

\section{Wstęp}

Jądro frazy nominalnej, $\mathrm{w}$ naszym przypadku rzeczownik, może zostać uzupełnione przez przydawki przymiotne, rzeczowne, przyimkowe, apozycje, zdania względne etc. (Bußmann 1990: 529). Sposób uzupełnienia rzeczownika będącego jądrem frazy nominalnej nie jest arbitralny, lecz podlega określonym restrykcjom syntaktycznym. Jądro frazy nominalnej może zostać rozbudowane dzięki różnym przydawkom z różnych poziomów zależności. Przydawki te mogą stać w pre- i postpozycji w stosunku do jądra. Jak wyjaśnia Weinrich (1993: 356), możliwości rozbudowywania frazy nominalnej zależą od pamięci kontekstowej (krótkoterminowej) recypującego, ponieważ zmuszony on jest do zapamiętania wszystkich determinantów znajdujących się przed i/lub za jądrem frazy nominalnej. Ilość elementów rozszerzających frazę musi być więc ograniczona pojemnością pamięci kontekstowej percypującego.

Poniżej szczegółowo przedstawimy możliwości rozbudowywania frazy nominalnej $\mathrm{w}$ języku niemieckim i polskim po prawej stronie rzeczownika, uwzględniając relacje syntaktyczne między nadrzędnikiem a podrzędnikiem. 


\section{Rozwijanie przydawek niemieckich i polskich wg Schattego i Jodłowskiego}

O skupieniach przydawek nominalnych (wyrażonych rzeczownikiem w dopełniaczu) i przyimkowych na przykładzie języka niemieckiego i polskiego pisze Schatte (1981: 82). Za Schenkelem (1972) wprowadza on dwa terminy charakteryzujące skupienia przydawek nominalnych w języku niemieckim, tj. szereg dopełniaczowy (genitivische Reihe) i lańcuch dopełniaczowy (genitivische Kette). Pod pojęciem szeregu dopełniaczowego Schatte rozumie człony rozszerzenia uporządkowane parataktycznie (współrzędnie). Łańcuch dopełniaczowy posiada natomiast człony uporządkowane hipotaktycznie (podrzędnie). Pojęcie szeregu i lańcucha odnosi się również do przydawek przyimkowych. Językoznawca zwraca uwagę na ściśle określony szyk wyrazów, jaki powinien obowiązywać - w przypadku przydawek przyimkowych niepołączonych spójnikiem - w szeregu składającym się z rzeczownika dewerbalnego jako jądra nominalnego. Kolejność przydawek przyimkowych połączonych spójnikiem w szeregu jest dowolna, analogicznie jak w szeregu utworzonym przez przydawki dopełniaczowe, np.

\section{szereg:}

- w przydawce rzeczownej:

(1) das Spiel der Geigen und (der) Flöten / das Spiel der Flöten und (der) Geigen

(2) pisanie dtugopisem lub piórem / pisanie piórem lub długopisem

- w przydawce przyimkowej:

(3) der Verkehr auf Wegen und (auf) Straßen / der Verkehr auf Straßen und (auf) Wegen

(4) książki dla dzieci i młodzieży / książki dla młodzieży i dzieci

\section{lańcuch:}

- w przydawce rzeczownej:

(5) die Diskussion der einzelnen Punkte der Tagesordnung der Konferenz der Außenminister der Mitgliedstaaten der antifaschistischen Allianz des letzten Weltkrieges

(6) sposoby eliminacji zanieczyszczeń powietrza

- w przydawce przyimkowej:

(7) in der Frage nach den Problemen in seinen Ausführungen über die Freiheit auf dem Gebiete der Kunst während der 3oer Jahre in Europa

(8) wiadomość o przyjęciu na studia

Przydawka wieloczłonowa - wg Helbiga/Buschy (1984: 600) - znajduje szczególne zastosowanie $\mathrm{w}$ językach specjalistycznych oraz mediach przekazujących wszelkiego rodzaju informacje z różnych dziedzin fachowych. Jak twierdzi Schatte (1981: 83), to dzięki nagromadzeniom przydawek rzeczownych „fraza nominalna nadaje się do oddawania kompleksowych i skomplikowanych kontekstów", ale z drugiej strony przydawki rozbudowane nie są łatwe dla czytelnika w percepcji. Sposób przyporządkowania przydawek (hipo- i parataktycznie) oraz różne ich struktury formalne dopuszczają powstanie wielu rozmaitych kombinacji, co może prowadzić do nieprzejrzystości i/lub polisemii treści zawartej w komunikacie. Rozbudowane przydawki często stanowią jeden $\mathrm{z}$ głównych problemów dla tłumaczy tekstów fachowych. Nawet doświadczeni tłumacze mają trudności $\mathrm{z}$ poprawnym przełożeniem treści skondensowanych $\mathrm{w}$ grupach nominalnych posiadających kilka członów wokół jądra nominalnego. Największe wyzwanie stanowi bowiem ułożenie przydawek $\mathrm{w}$ translacie $\mathrm{w}$ 

niemieckim i polskim

odpowiedniej kolejności oraz fakt, że ich ekwiwalenty mogą należeć do innych kategorii morfologicznych.

Przydawki wieloczłonowe znane są także w polszczyźnie pod pojęciem przydawek w postaci skupień wyrazowych (Strutyński 2002: 309). Z kolei Jodłowski (1977: 85) nazywa je przydawkami rozwiniętymi, np.

(9) Ojciec przyjąt ze smutkiem wiadomość o przejściu na emeryturę

(10) Dzień przedtem dokonat $w$ swej kancelarii aktu sprzedaży najuiększych lasów w województuvie

W powyższych przykładach przydawki rozwinięte tworzone są w ten sposób, że kolejne przydawki są charakteryzowane przez dalsze określenia, będące następnymi przydawkami. W terminologii Schattego odpowiada to łańcuchom przydawkowym, a więc zjawisku wieloczłonowości przydawek.

\section{Rozwijanie przydawek niemieckich wg Weinricha}

Weinrich (1993: 432) wychodzi z założenia, że tylko przymiotniki $\mathrm{w}$ funkcji przydawki oraz ich determinanty wtórne mogą stać w ramie nominalnej, tj. przed rzeczownikiem. Przydawki takie nazywa prädeterminierende Attributte (przydawkami pre-determinującymi). Natomiast wszystkie pozostałe przydawki rzeczownika stoją poza ramą nominalną, stąd nazywane są przez niego postdeterminierende Attribute (przydawkami post-determinującymi). Do przydawek tych lingwista zalicza:

1. adjunkty ${ }^{1}$ dopełniaczowe (Genetiv-Adjunkte), np.

(1) das Rathaus der Stadt ist für sein Glockenspiel berühmt

(2) Bürgermeister Rostocks will das Rathaus renovieren lassen

(2a) Rostocks Bürgermeister will das Rathaus renovieren lassen

(3) der Giebel des Rathauses in Münster

Adjunktów dopełniaczowych używa się głównie w funkcji przydawki i dlatego określa się je często przydawkami dopełniaczowymi. Stoją one za rzeczownikiem. Jedynie nazwy własne $w$ dopełniaczu mogą zajmować miejsce przed rzeczownikiem (2a). Jeżeli za rzeczownikiem stoją dwie przydawki różnego rodzaju, to pierwszeństwo ma zawsze przydawka dopełniaczowa przed przyimkową (3).

2. adjunkty przyimkowe (Präpositional-Adjunkte), np.

(4) der Brunnen vor dem Tor war in früheren Zeiten ein Treffpunkt für die jungen Mädchen aus dem Ort

Adjunkty przyimkowe w funkcji przydawkowej występują bezpośrednio za rzeczownikiem, do którego się odnoszą.

3. adjunkty spójnikowe (Konjunktional-Adjunkte), $\mathrm{np}$.

(5) die Frage, ob die Stadt am Fluss ihren alten Glanz je wieder finden würde, beschäftigte viele Einwohner

(6) heute muss man die Hoffnung aufgeben, dass die jungen Leute eines Tages zurückkehren

${ }^{1}$ Używanej w terminologii gramatyków lipskich przydawce predykatywnej odpowiada u Engla termin Adjunkt (1988: 158), z którego korzysta również Weinrich, a który u Engla oznacza przydawkę przesuwną (dislozierbares Attribut) do rzeczownika lub zaimka. 
Adjunkty spójnikowe w funkcji przydawkowej występują jedynie przy nielicznych rzeczownikach, zazwyczaj derywatach odczasownikowych. Zawsze zajmują one pozycję za jądrem frazy nominalnej.

4. adjunkty bezokolicznikowe (Infinitiv-Adjunkte), np.

(7) der Vorschlag, den Marktplatz neu zu pflastern, wurde in der Stadtverordnetenversammlung positiv aufgenommen

Adjunkty bezokolicznikowe tworzące określenie przydawkowe do rzeczownika mogą zajmować pozycję wyłącznie za nim.

5. adjunkty relatywne (Relativ-Adjunkte), np.

(8) die Stadt, die im 12. Jahrhundert gegründet wurde, war lange Zeit ein wichtiger Knotenpunkt

Również adjunkty relatywne mogą - tak samo jak adjunkty bezokolicznikowe zajmować pozycję tylko za jądrem frazy nominalnej, ponieważ odnoszą się one bezpośrednio do rzeczownika.

6. przysłówki atrybutywne (attributive Adverbien), np.

(9) die Leute hier freuen sich schon sehr darauf

(10) das Stadtteilfest heute Abend ist ein wichtiges Ereignis

Tylko kilka rodzajów przysłówków może pełnić funkcję przydawki w grupie nominalnej, stojąc za jej jądrem. Są to głównie przysłówki miejsca (9) lub czasu (10).

Weinrich (1993: 361) podaje również zasady rozbudowywania frazy nominalnej o kilka przydawek postdeterminujących na następujących przykładach: (11) die Kinder der Bauern aus den Dörfern, die auf die höhere Schule gingen, mussten früher oft einen weiten Weg in Kauf nehmen

(12) die Bekanntmachung des Direktors in der Lehrerkonferenz, dass ein Schulbus eingeführt wird, wurde mit Erleichterung aufgenommen Wynika $\mathrm{z}$ nich następująca kolejność przydawek prawostronnych we frazie nominalnej: adjunkty dopełniaczowe, adjunkty przyimkowe, adjunkty spójnikowe lub bezokolicznikowe albo względne.

\section{Rozwijanie niemieckich i polskich fraz nominalnych wg zasad konotacji (walencji)}

Kolejnym tematem naszych rozważań są sposoby rozbudowywania fraz nominalnych wg wymagań składniowych nadrzędnika. Zarówno w języku niemieckim, jak i polskim poszczególne pozycje składniowe rzadko realizowane są przez proste grupy nominalne. Najczęściej dochodzi do rozwinięcia rzeczownika przez dodanie podrzędnych członów rozwijających nadrzędnik. Rozbudowywanie frazy nominalnej opiera się między innymi na powiązaniach konotacyjnych.

Konotacja to zapowiadanie przez daną formę wyrazową innej jednostki składniowej, zwanej w terminologii Saloniego i Świdzińskiego (2001: 222 i n.) frazą wymaganą (konotowaną przez daną formę wyrazową). Może nią być m. in. grupa wyrazowa, zdanie składowe podrzędne, zdanie składowe właściwe, zdaniereszta. Fraza wymagana musi być dołączona do danej formy wyrazowej, aby wypowiedzenie było pełne, czyli nieeliptyczne.

Taką samą definicję konotacji przyjmuje także Nagórko (2003: 267). Polega ona - jej zdaniem - na otwieraniu pustych miejsc zapowiadajaccych pojawienie się obok danego wyrazu (formy) jakiegoś innego wyrazu (formy). 
Wg Saloniego/Świdzińskiego (op. cit.) istnieją trzy typy oddziaływań konotacyjnych: konotacja podrzędnika, konotacja niepodrzędnika i konotacja współskładnika. Konotacja podrzędnika oznacza wymuszanie przez wyraz innych form wyrazowych pozostających w stosunku do niego w relacji podrzędności, np. Tomasz kupit samochód. Konotacja niepodrzędnika to dostrzeżenie konieczności wystąpienia innego wyrazu wraz $\mathrm{z}$ wyrazem analizowanym, przy czym wyraz konotowany nie będzie pozostawał w stosunku podrzędności wobec wyrazu analizowanego. Konotacja współskładnika polega na wymuszeniu przez jeden element innego elementu, z którym ten pierwszy tworzy całość, np. leksem że wymusza współskładnik zdaniowy, z którym utworzy on zdanie składowe podrzędne.

W przeciwieństwie do Saloniego/Świdzińskiego Nagórko (2003: 269) rozróżnia tylko dwa typy konotacji jako potencji systemu leksemów. Konotacja kategorialna zapowiada określoną kategorię leksykalno-morfologiczną (przymiotnik $\rightrightarrows$ rzeczownik). Konotacja formalna zapowiada określoną formę gramatyczną i jest odwrotnością akomodacji, np. biat-a $\rightrightarrows$ chust-a.

Saloni/Swidziński (2001: 243 i n.) oraz Nagórko (2003: 270) wprowadzają pojęcie konotacji wielokrotnej i alternatywnej. $Z$ tą pierwszą mamy do czynienia, gdy wyraz konotuje więcej niż jeden podrzędnik lub więcej niż jeden współskładnik. Nie jest natomiast konotacją wielokrotną równoczesne konotowanie nadrzędnika i jednego podrzędnika lub jednego współskładnika. Jeżeli z kolei wyraz konotuje albo jeden typ podrzędnika, albo drugi typ podrzędnika mówimy o konotacji alternatywnej, np. wierzy matce; wierzy, że matka przyjdzie. U Nagórko (op. cit.) konotacja alternatywna zawsze związana jest ze zmianą znaczeniową konotatora, np. farbować włosy, bluzka farbuje.

Kolejne rozróżnienie zaproponowane przez Saloniego/Świdzińskiego (2001: 245 i n.) oraz Nagórko (2003: 269 i n.) dotyczy konotacji obligatoryjnej, fakultatywnej i wzajemnej. Konotacja obligatoryjna oznacza bezwzględną konieczność wystąpienia formy lub form konotowanych przez dany wyraz, np. skrytykowat kolegę. Zdanie nie może mieć charakteru elipsy. Konotacja wzajemna dotyczy wymagania podrzędnika przez nadrzędnik i nadrzędnika przez podrzędnik, np. zabit ofiarę. Nagórko (2003: 273) stoi na stanowisku, że czasowniki wymagają określonych przyimków, a przyimki określonych czasowników. Tę zależność określa terminem konotacja wzajemna. Ponadto Nagórko mówi o konotacji dwustronnej wyrazów funkcyjnych takich, jak spójniki oraz zaimki względne. Konotują one dwustronnie określony typ frazy, np. spójniki konotują frazy współrzędne albo niewspółrzędne. Konotacja fakultatywna pojawia się wtedy, gdy obecność wyrazu konotowanego jest możliwa, ale nie obowiązkowa, np. czytam ksiażkę.

Powyższe rozróżnienie pozwoliło Saloniemu/Świdzińskiemu (2001: 248) na zdefiniowanie frazy wymaganej i niewymaganej. Fraza wymagana to taka, która pojawić się musi; zaś fraza niewymagana to taka, która „konotuje nadrzędnik, sama zaś nie jest konotowana”.

Jak pisze Grzegorczykowa (1999: 54), konotacja podrzędnika przez rzeczownik ma miejsce głównie w przypadku:

1. rzeczowników relacyjnych, np. ojciec, matka, oraz rzeczowników typu kawatek, odcinek, typ,

2. rzeczowników odczasownikowych dziedziczących konotacje swoich wyrazów bazowych, np. kupowanie książek. 
Podobnie zjawisko konotacji rozumie Wróbel (2001: 225), chociaż posługuje się w tym wypadku terminem walencja czynna. W opracowanym przez niego podręczniku akademickim do gramatyki języka polskiego podstawowym kryterium opisu składni jest opis reguł formalno-składniowych. Dla budowy struktury formalnej każdej wypowiedzi konieczne są środki słownikowe i gramatyczne. Środki słownikowe to - zdaniem Wróbla - "tkwiąca w każdym leksemie możliwość (lub niemożliwość) łączenia się ze ściśle określonymi typami innych leksemów w konstrukcję składniową" (Wróbel 2001: 224). Właśnie ta możliwość nazywana jest walencją. Językoznawca rozpatruje walencję na dwóch płaszczyznach. Z jednej strony są to bierne możliwości łączenia się jednego leksemu z innymi leksemami, z drugiej zaś chodzi o czynne zdolności przyłączania (domagania się) innych leksemów. Stąd u Wróbla występują dwa terminy: walencja czynna i walencja bierna.

Walencja bierna odpowiada $\mathrm{w}$ istocie terminowi dystrybucji danego leksemu. Jest to „suma wszystkich różnych (nieidentycznych) pozycji, w jakich może on i nie może wystąpić w otoczeniu innych typów leksemów lub ich połączeń w poprawnie zbudowanym komunikacie językowym” (Wróbel 2001: 224). Dystrybucja leksemów ma zatem charakter kategorialny i jest podstawą podziału wyrazów na klasy funkcjonalne, czyli części mowy.

Walencja czynna oznacza - jak już wcześniej nadmieniono - konotację danego leksemu rozumianą jako jego cecha indywidualna, słownikowa. Wróbel (op. cit.) określa poprzez nią „sumę typów innych leksemów i ich połączeń, których się on domaga, gdy z jego udziałem tworzymy konstrukcję składniową”. To właściwości konotacyjne leksemów (walencja czynna) wyznaczają schematy konstrukcji zdaniowych i są bardzo istotne dla składni.

W odróżnieniu od języka polskiego język niemiecki operuje wyłącznie pojęciem walencji lub wartościowości (Valenz/Wertigkeit) ${ }^{2}$ na określenie konotacji. Kiedyś pojęcie to było przede wszystkim zarezerwowane dla czasownika (por. Tesniére 1966), ponieważ proces konotacji odgrywa podstawową rolę przy tworzeniu zdania. Od konotacji bowiem zależy, jakie człony i ile z nich powinno lub może wystąpić w zdaniu, aby było ono poprawne gramatycznie. Pojęcie walencji pochodzi od Tesniére'a (1966). Jak podaje EJO (1999: 629), walencja w rozumieniu Tesniére’a to „zdolność wyrażeń do otwierania wokół siebie miejsc, czyli pozycji dla innych wyrażeń. Zdolność ta jest zależna od właściwości reprezentowanych przez nie struktur sensu". Definicja ta przejmowana jest w późniejszych pracach polonistycznych, m. in. przez Puzyninę (1969), Buttler (1976), Niemczuk (1985) i Wróbla (2001: 238), oraz germanistycznych, m. in. przez Engla (1988: 885): „Valenz - Eigenschaft von Subklassen bestimmter Wortklassen (besonders Verben, Adjektive, Nomina), andere Elemente zu regieren“. Walencja występuje nie tylko przy czasowniku, lecz także przy wszystkich innych wyrazach mogacych posiadać uzupełnienia, np. rzeczownik Hoffnung może utworzyć następującą frazę nominalną: die Hoffnung der

\footnotetext{
2 Ponieważ szczegółowe opisanie problemów walencji oraz jej rodzajów (walencja logiczna, semantyczna, syntaktyczna) w j. niemieckim wykracza poza ramy niniejszego artykułu, odsyłamy do literatury specjalistycznej, tj. pozycji Helbiga/Schenkela (1969), Helbiga (1976), Stepanovej/Helbiga (1981), Dębskiego (1987), Engla (1988). Dla nas punktem wyjścia jest trójstopniowy model walencji Helbiga i Schenkela.
} 


\section{Artur Dariusz Kubacki: Zasady rozbudowywania frazy nominalnej w języku niemieckim i polskim}

Menschen auf Frieden. Stąd można powiedzieć, że rzeczownik ten posiada walencję typu: „genetivus subiectivus” i „präpositives Attribut” (Engel 1988: 24).

Golonka (2002: 366) rozszerza definicję walencji Engla i rozumie ją w dość szerokim zakresie jako właściwość kombinacyjną słów mających autonomiczne znaczenie wpływające na cechy semantyczne, funkcję syntaktyczną oraz częściowo funkcję morfologiczną elementów w obrębie swojego sąsiedztwa.

W językoznawstwie niemieckim dominuje już od wielu lat pogląd, że nie tylko czasownik (tak uważał Tesniére), ale i inne kategorie morfologiczne posiadają swoją walencję, m. in. rzeczownik (Stepanova/Helbig 1981: 128) ${ }^{3}$. Używając kategorii walencji, ustala się następujące jej właściwości (EJO 1999: 629):

1. liczbę otwieranych pozycji i stopień obligatoryjności ich wypełnienia, czyli liczbę wymaganych i liczbę dopuszczanych przez te wyrażenia uzupełnień,

2. semantyczne cechy wyrażeń uzupełniających,

3. strukturalne cechy wyrażeń uzupełniających, czyli typ i postać wskaźników syntaktycznych.

Ze względu na pierwsze kryterium autorzy EJO (op. cit.) wyróżniają wyrażenia monowalentne (jednomiejscowe) i poliwalentne (wielomiejscowe) lub awalentne (niemające w ogóle walencji). Ustalając liczbę uzupełnień przy wyrażeniach, należy zwrócić uwagę na odróżnienie uzupełnień bezwzględnie wymaganych (uzupełnienia obligatoryjne) od uzupełnień przez nie dopuszczanych (uzupełnienia fakultatywne). W celu stwierdzenia, czy uzupełnienie jest obligatoryjne czy fakultatywne, stosuje się test usuwalności polegający na ocenie wyrażenia zdaniowego pod względem jego niegramatyczności 4 .

$\mathrm{Na}$ podstawie drugiego kryterium uzupełnienia opisuje są semantycznie. W tym celu określa się semantyczne cechy selekcyjne wyrażeń.

Kryterium trzecie wykorzystuje się do opisu formalnych postaci wyrażeń uzupełniających. Tu nieodzowne są formalne cechy selekcyjne wykorzystujące formuły złożone z symboli kategorialnych.

Zgodnie $\mathrm{z}$ wymienionymi powyżej kryteriami istnieją $\mathrm{w}$ języku niemieckim jak podają Sommerfeld/Schreiber (1977: 24 i n.) - rzeczowniki bez tzw. aktantów (argumentów), z jednym, dwoma lub trzema aktantami. Stepanova/Helbig (1981: 182) łączą ten podział - wychodząc od ilości aktantów rzeczownika - z klasami semantycznymi tej kategorii mowy, co daje następujący obraz:

1. rzeczowniki zerowartościowe oznaczające $\mathrm{z}$ reguły procesy, $\mathrm{w}$ tym najczęściej zjawiska przyrodnicze, np. das Blitzen,

2. rzeczowniki jednowartościowe oznaczające:

2.1. czynności, np. das Scharren der Pferde,

2.2. procesy, np. das Fallen des Laubs,

\footnotetext{
3 Pod koniec lat 6o. i w latach 70. oraz 80. powstały w Niemczech pierwsze słowniki walencji i dystrybucji niemieckich czasowników (por. Helbig/Schenkel 1969), rzeczowników (Sommerfeld/Schreiber 1977) i przymiotników (Sommerfeld/Schreiber 1983). W Polsce pierwszy Stownik syntaktyczno-generatywny czasowników polskich obejmujący 6 tomów został opracowany pod red. K. Polańskiego w latach 1980-1992. Natomiast pierwszy słownik walencji niemiecko-polski, polsko-niemiecki w opracowaniu Morcińca, Cirko i Ziobro powstał w 1995 roku.

4 Helbig (1976) uważa, że rzeczowniki na poziomie syntaktycznym nie posiadają aktantów obligatoryjnych, tylko fakultatywne. Brak aktantów może wypełnić informacja zawarta w makrokontekście.
} 


\section{3. stany, np. der Schlaf des Jungen,}

2.4. właściwości, np. die Größe des Sportlers,

3. rzeczowniki dwuwartościowe oznaczające:

3.1. właściwości:

a) pochodzące od czasowników przechodnich, np. die Besichtigung der Ausstellung durch die Besucher,

b) pochodzące od czasowników nieprzechodnich, np. der Kampf des Volkes um die Befreiung,

3.2. stany, np. die Freude des Schriftstellers über den Erfolg,

4. rzeczowniki trójwartościowe oznaczające:

4.1. czynności, np. die Lieferung der Ware an die Verkaufsstellen durch den Großhandel,

4.2. właściwości, np. die Dankbarkeit des Schülers gegenüber seinem Lehrer für die Unterstützung.

Również w języku polskim rzeczownik posiada swoją wartościowość, określoną powyżej przez Wróbla jako walencja czynna. Uzupełnienia obligatoryjne to człony konotowanej przez nadrzędnik (rzeczownik) konstrukcji składniowej zwane członami obowiązkowymi. Uzupełnienia fakultatywne to człony niekonotowane, lecz swobodnie dodane do nadrzędnika, zwane członami luźnymi.

Szczegółowy przegląd własności konotacyjnych poszczególnych części mowy w języku polskim przedstawił jako pierwszy Milewski (1965: 97 i n.). Ze względu na właściwości konotacyjne wszystkie wyrazy podzielił na:

1. wyrazy prymarne - niczego nie konotują, same zaś są konotowane przez wyrazy sekundarne; należą tu rzeczowniki (np. dom, wilk, białość, pisanie),

2. wyrazy sekundarne - przymiotniki konotujące wyrazy prymarne w tym samym przypadku, liczbie i rodzaju i otwierające obok siebie miejsce dla rzeczowników, tworzące schematy zdaniowe grupy nominalnej (np. biaty, wysoki, ojcowski, zgnity), i czasowniki oznaczające stan lub czynność wymagające agensa i pacjensa oraz konotujące rzeczowniki (np. siedzi, bije, leży, bieleje),

3. wyrazy tercjarne - konotują wyrazy sekundarne, tj. przymiotniki i czasowniki, nie będąc konotowane przez żadną inną klasę wyrazów; Milewski zalicza tu przysłówki (np. dobrze, wesoło, bardzo, góra).

W systemie konotacji występują u Milewskiego również zaimki i liczebniki mające swoje odpowiedniki o tym samym typie konotacji wśród rzeczowników, przymiotników i przysłówków. Wyrazami prymarnymi są zaimki rzeczowne (np.ja, ty) oraz liczebniki główne (np. dwa, pięć). Do wyrazów sekundarnych trzeba zaliczyć zaimki dzierżawcze (np. mój, wasz) i liczebniki porządkowe (np. drugi, piąty). Wyrazami tercjarnymi są zaś zaimki przysłowne (np. tu, tam) oraz liczebniki przysłówkowe (np. dwojako, trojako).

Szczegółowy przegląd własności konotacyjnych polskich rzeczowników 5 i innych części mowy, uzupełniony o informacje dotyczące dystrybucji (walencja bierna), przedstawia Wróbel (2001: 243 i n.). Jak podaje badacz, rzeczowniki polskie konotują:

5 W literaturze polonistycznej walencją semantyczną rzeczowników polskich zajmowała się szczegółowo także Niemczuk-Weiss (1985:155 i n.; 1992: 106 i n.). 
a) rzeczowniki i wyrażenia przyimkowe, np.

odporność $\Rightarrow$ [na przeziębienie], wywiad [Kowalskiego] $\Rightarrow$ [z ministrem],

b) wybrane przymiotniki (dzierżawcze) ${ }^{6}$, np. brat $\Rightarrow$ [mój],

c) odpowiednie typy zdań składowych, np.

twierdzenie $\Rightarrow[\dot{z} e . .$.$] , pytanie \Rightarrow[$ czy.../kto.../kiedy... itp.],

d) zero (także forma wołacza), np. Piotr, kot, ja, ty, Piotrze.

Wróbel (op. cit.) zwraca uwagę na rzeczowniki odczasownikowe i odprzymiotnikowe transpozycyjne, które przejmują po części własności konotacyjne wyrazów podstawowych, np. konotację podrzędników (pytać o drogę, pytanie o drogę). Ponadto rzeczowniki współwystępują z nadrzędnikami, którymi są:

a) formy określone czasowników, np. dziecko (śpi),

b) formy rzeczowników, np. (choroba) chtopca,

c) formy przymiotników, np. (wstrętny) ciotce.

Podobnie jak Sommerfeld i Schreiber (1977), Niemczuk (1985: 162 i n.) stosując kryterium liczby aktantów (argumentów) - dokonała podziału polskich rzeczowników odczasownikowych (substantiva verbalia) o formantach -anie, -enie, -cie o znaczeniu procesualnym (nomina actionis). Wyróżniła ona:

1. substantiva verbalia jednowalentne:

a) agens: brzmienie głosu, pęknięcie rury,

2. substantiva verbalia biwalentne:

a) agens - obiekt: potracenie przechodnia przez samochód,

b) agens - adresat: zaufanie Jurkowi przez matkę,

c) agens - miejsce: mieszkanie Piotra na poddaszu,

d) agens - punkt docelowy: dojście Janka do szkoły,

e) agens - punkt wyjścia: wystapienie rzeki z brzegów,

f) agens - lokalizator: wstapienie Piotra do organizacji,

3. substantiva verbalia triwalentne:

a) agens - obiekt - narzędzie: nakrycie stohu obrusem przez matke,

b) agens - obiekt - środek: doprawienie zupy przyprawa przez matkę,

c) agens - obiekt - adresat: przedstawienie uczniom pisarza przez nauczyciela,

d) agens - obiekt - przyczyna: zabezpieczenie pieniędzy przed kradzieżą przez kasjera,

e) agens - obiekt - punkt docelowy: doprowadzenie alkoholika do izby wytrzeźwień przez milicjantów,

f) agens - obiekt - limitator: osiąnięcie sukcesów przez sportowca $w$ plywaniu,

g) agens - obiekt - cel: przeznaczenie przez dyrekcję maszyn na sprzedaż,

h) agens - obiekt - sposób: dzielenie pożywienia przez ojca rodziny pomiędzy dzieci,

i) agens - adresat - treść: zawiadomienie mieszkańców przez dozorcę o wylaczeniu wody,

4. substantiva verbalia czterowalentne:

${ }^{6}$ Zaimki dzierżawcze Wróbel zalicza do przymiotników. 
a) agens - adresat - obiekt - II obiekt:

Jana,

dopowiedzenie Piotrowi argumentów do jego wypowiedzi przez

b) agens - obiekt - środek - przyczyna:

odznaczenie żotnierza za męstwo orderem przez generała,

c) agens - obiekt - adresat - treść:

opowiadanie uczniom ciekawostek o życiu zwierząt przez nauczyciela,

5. substantiva verbalia pięciowalentne:

a) agens - obiekt - punkt wyjścia - punkt docelowy - cel:

skierowanie uczniów z małego miasta do Warszawy na studia przez radę pedagogiczną.

Niemczuk (op. cit.) stwierdza, że najmniej licznie reprezentowane są rzeczowniki odczasownikowe cztero- i pięciowalentne, a najwięcej możliwości tworzenia schematów logiczno-semantycznych wykazują substantiva verbalia triwalentne.

Na koniec naszych rozważań chcemy zwrócić uwagę na to, że niektórzy polscy językoznawcy, m. in. Grzegorczykowa (1999: 53), oddzielają pojęcie konotacji od walencji. Przez konotację rozumie ona wymagania semantyczno-składniowe (morfologiczne) leksemów, a przez walencję - podobnie jak Bühler (1934) „otwieranie miejsc” dla pozycji semantycznych. Wymagania konotacyjne różnych jednostek językowych rozumiane są zarówno składniowo, jako warunek sine qua non nieeliptyczności, jak i semantycznie - jako warunki kompletności znaczeniowej, tzw. pełnoznaczności (por. Bühler 1934; Buttler 1976). W niniejszym artykule będziemy posługiwać się pojęciem konotacja jako właściwością leksemu polegającą na wymaganiu wystąpienia podrzędnika uzupełniającego znaczeniowo treść leksemu (por. Zaron 1988: 114; Grzegorczykowa 1999: 51).

Z literatury dotyczącej walencji (konotacji) wynika, że rzeczowniki pochodzące od czasowników nabywają wiele cech walencyjnych od wyrazów, od których pochodzą (por. Sommerfeld/Schreiber 1977: 13; Engel 1988: 505; Eroms 2000: 284; Golonka 2002: 366). Zjawisko to określa się mianem dziedziczenia walencji (Valenzvererbung) lub dziedziczenia werbalnych cech walencji (Vererbung verbaler Valenzmerkmale). Nasze kolejne rozważania poświęcone są dziedziczeniu walencji oraz jego rodzajom na przykładzie derywatów z -ung.

\section{Sposoby dziedziczenia konotacji przez rzeczowniki dewerbalne $\mathrm{z}$-ung}

\subsection{Uwagi teoretyczne}

O dziedziczeniu walencji przez rzeczowniki dewerbalne $\mathrm{z}-u n g$ wspominają już $\mathrm{w}$ 1981 r. Stepanova/Helbig. Badacze (1981: 180) stwierdzają, że derywaty z -ung przejmują tylko wtedy walencję od tworzącego je czasownika, jeżeli zachowują jego procesualny charakter (tworzą nomina actionis). Jeżeli natomiast rzeczowniki dewerbalne wyrażają rezultat procesu (tworzą nomina acti/nomina resultati), wówczas ich walencja jest inna od walencji czasownika. Dlatego też derywat Lieferung jako nomina actionis (1) zachowuje walencję czasownika, zaś jako nomina acti (2) ma od niego inną walencję, np.

(1) Die Lieferung der Lebensmittel durch den Großhandel an die Gaststätte erfolgte regelmäßig 
(2) Er kontrollierte die eingegangene Lieferung des Großhandels an seine Gaststätte

O związkach walencyjnych zachodzących pomiędzy interpretacją rodzajową a strukturą argumentową nominalizacji z -ung piszą Ehrich i Rapp (2000) w artykule pt. „Sortale Bedeutung und Argumentstruktur: ung-Nominalisierungen im Deutschen”. W swoich rozważaniach badaczki zajmują się rzeczownikami dewerbalnymi z -ung, które przejmują typ sytuacyjny ze swojej werbalnej podstawy słowotwórczej. Nominalizacje te posiadają często te same argumenty tematyczne jak czasownik, jednak realizowane $\mathrm{w}$ inny sposób. $\mathrm{Z}$ tego powodu argumenty czasownika pojawiają się podczas nominalizacji albo wewnątrz leksemu (jako człon pierwszy = określający), albo na zewnątrz leksemu (jako przydawka prenominalna lub postnominalna albo jako wyrażenie przyimkowe). Zamiarem badaczek niemieckich jest przedstawienie relacji zachodzących pomiędzy członem określanym i dopełniaczem postnominalnym, np.

(3) Der Präsident ernennt den Kanzler:

(3a) die Kanzlerernennung

(3b)die Ernennung des Kanzlers

(3c) die Kanzlerernennung des Präsidenten

człon pierwszy $=\mathrm{OBIEKT}_{\mathrm{AKK}}$

Genetiv $=$ OBIEKT $_{\mathrm{AKK}}$

człon pierwszy $=\mathrm{OBIEKT}_{\mathrm{AKK}}$,

Genetiv $=$ SUBIEKT

Jak sugerują powyższe przykłady, dopełnienie w bierniku czasownika jest realizowane zawsze $\mathrm{w}$ pierwszej kolejności podczas rozbudowywania frazy nominalnej (Nominallinking). Ponadto przy równoczesnym obsadzeniu obydwu pozycji człon pierwszy odpowiada dopełnieniu w bierniku, dopełniacz odpowiada natomiast podmiotowi. Patrząc $\mathrm{z}$ tej perspektywy, Nominallinking byłby determinowany wyłącznie przez reguły dziedziczenia argumentów. Jak dowodzą Ehrich i Rapp, wiele przykładów w jednoznaczny sposób świadczy przeciwko temu czysto morfosyntaktycznemu podejściu w teorii dziedziczenia argumentów, np.
(4) die Dioxionbelastung
(5) die Bewunderung der Fans
człon pierwszy $=$ SUBIEKT
$\mathrm{OBIEKT}_{\mathrm{AKK}}$
(6) die Alkoholgefährdung der Jugend
Genetiv $=$ SUBIEKT lub
człon pierwszy $=$ SUBIEKT, Genetiv $=$ OBIEKT $_{\mathrm{AKK}}$

Ehrich i Rapp reprezentują pogląd, iż poprawne rozbudowywanie frazy nominalnej odbywać się może jedynie z uwzględnieniem semantycznej struktury nominalizacji. W przypadku rozbudowywania fraz za pomocą genetiwu istotną rolę odgrywają struktury zdarzeniowe i przyczynowe, natomiast w przypadku realizacji członu pierwszego ważne są hierarchie tematyczne. W centrum zainteresowania znajduje się interakcja obydwu pozycji realizacyjnych: jest ona sterowana przez reguły dziedziczenia argumentów sięgające także do struktury leksykalnosemantycznej rzeczownika. W swoich rozważaniach badaczki rezygnują $\mathrm{z}$ analizy złożeń, w których pojawiają się derywaty z -ung, na korzyść interpretacji fraz dopełniaczowych powstających podczas nominalizacji procesu i rezultatu. Do najważniejszych wniosków autorek należy zaliczyć fakt, że syntaktyczna realizacja argumentów bezpośrednio wynika z semantycznej reprezentacji nominalizacji. Zatem to nie reguły dziedziczenia argumentów oparte na zasadach czysto morfosyntaktycznych, lecz semantyka decyduje o rozbudowywaniu frazy nominalnej. 
Realizacja poszczególnych argumentów podczas procesu nominalizacji została pokazana przez Ehrich i Rapp (2000: 267) na przykładzie wieloznacznego czasownika Bemalung:

(7) Er ist bei der Bemalung der Wand vom Stuhl gefallen

(PROCES)

(8) Nach der Bemalung der Wand sind die Kinder davongelaufen (ZDARZENIE)

(9) Die Bemalung der Wand besteht unverändert fort

(STAN REZULTATU)

(10)Der Hausmeister hat die Bemalung der Wand entfernt ～(OBIEKT REZULTATU)

Zgodnie $\mathrm{z}$ morfosyntaktycznym podejściem do dziedziczenia argumentów sufiks -ung podczas nominalizacji przekazuje dopełnienie w bierniku z podstawy werbalnej do rzeczownika, tworząc postnominalną frazę dopełniaczową (Toman 1983: 54 i n.). Zatem sufiks -ung może zmieniać w specyficzny sposób syntaktyczną metodę realizacji argumentów swoich baz. Często zakłada się, że w niemczyźnie nominalizacje dewerbalne dziedziczą dopełniacz zamiast biernika $\left(\mathrm{NP}_{\mathrm{AKK}} \Rightarrow \mathrm{NP}_{\mathrm{GEN}}\right)$. Rola semantyczna argumentów podczas procesu dziedziczenia jest przy tym bez znaczenia. Istotna jest tylko realizacja syntaktyczna kategorii bazy, w tym wypadku czasownika. Zaprzeczeniem tej tezy jest cytowany przez badaczki przykład, w którym nie występuje oczekiwany dopełniacz w genetiwie, lecz fraza przyimkowa, np.

(11) die Bewunderung für die Diva/der Diva

(12) die Verehrung für die Diva/der Diva

(13) die Forderung nach Reformen/von Reformen/der Reformen

Badaczki twierdzą, że semantyka nominalizacji z -ung jest o wiele ważniejsza podczas realizacji argumentów.

Przedstawione powyżej uwagi teoretyczne pozwolą nam na zbadanie podrzędnikowych konotacji odczasownikowych derywatów z -ung stanowiących centrum niemieckich fraz nominalnych oraz porównanie ich $\mathrm{z}$ konotacjami polskich odpowiedników derywatów z -ung.

\subsection{Konotacja frazy nominalnej na przykładach z badanego korpusu}

Zgodnie z omówionymi powyżej aspektami teoretycznymi dotyczącymi konotowania w obrębie frazy nominalnej przypomnijmy, iż w literaturze dokonano podziału konotacji na obligatoryjną, fakultatywną i alternatywną. Poniżej prezentujemy przykłady fraz z badanego korpusu dla tego typu konotacji oraz ich tłumaczenia na język polski, wskazując na zgodność (tab. 1-4) oraz brak zgodności (tab. 5-6) konotowanych fraz w języku niemieckim i polskim.

\subsubsection{Zgodność konotowanych fraz $w L_{1}$ i $L_{2}$}

Tabela 1. Konotacja obligatoryjna przydawki dopetniaczowej $w L_{1} i L_{2}{ }^{7}$

\begin{tabular}{|l|l|l|}
\hline $\mathbf{1}$ & $\begin{array}{l}\text { Przydawka dopełniaczowa } \\
\text { konotowana obligatoryjnie }\end{array}$ & $\begin{array}{l}\text { Przydawka dopełniaczowa } \\
\text { konotowana obligatoryjnie }\end{array}$
\end{tabular}

${ }^{7} \mathrm{~L}_{1}$ i $\mathrm{L}_{2}$ oznaczają odpowiednio: język wyjściowy, tj. j. niemiecki, oraz język docelowy, tj. j. polski. 
Artur Dariusz Kubacki: Zasady rozbudowywania frazy nominalnej w języku niemieckim i polskim

\begin{tabular}{|c|c|c|}
\hline $\mathrm{a}$ & Berücksichtigung der Beiträge & uwzględnienie składek \\
\hline $\mathrm{b}$ & Berechnung des Steuersatzes & naliczenie stawki podatkowej \\
\hline $\mathrm{c}$ & Übertragung des Pauschbetrags & przeniesienie kwoty ryczaltowej \\
\hline $\mathrm{d}$ & Überweisung des Betrags & przelanie kwoty \\
\hline $\mathrm{e}$ & Bestreitung des Lebensunterhalts & pokrycie kosztów utrzymania \\
\hline $\mathrm{f}$ & Abgeltung eines Sonderbedarfs & $\begin{array}{l}\text { zrekompensowanie } \\
\text { szczególnych }\end{array}$ \\
\hline $\mathrm{g}$ & Räumung einer Dienstwohnung & opuszczenie mieszkania stużbo \\
\hline $\mathrm{h}$ & Vollendung des dritten Lebensjahres & ukończenie trzeciego roku życia \\
\hline $\mathrm{i}$ & $\begin{array}{l}\text { Begründung der doppelten } \\
\text { Haushaltsführung }\end{array}$ & $\begin{array}{l}\text { uzasadnienie prowadzenia } \\
\begin{array}{l}\text { podwójnego } \\
\text { domowego }\end{array} \\
\end{array}$ \\
\hline $\mathbf{j}$ & Versteuerung des Arbeitslohns & $\begin{array}{l}\text { opodatkowanie wynagrodzenia za } \\
\text { prace }\end{array}$ \\
\hline $\mathrm{k}$ & $\begin{array}{l}\text { Beendigung der } \\
\text { Haushaltsführung }\end{array}$ & $\begin{array}{l}\text { likwidacja podwójnego prowadzenia } \\
\text { gospodarstwa domowego }\end{array}$ \\
\hline 1 & $\begin{array}{lll}\text { Sicherung der erforderlichen } \\
\text { Grundpflege }\end{array}$ & $\begin{array}{l}\text { zabezpieczenie niezbędnej opieki } \\
\text { podstawowej }\end{array}$ \\
\hline 1 & Leistungen des Arbeitgebers & świadczenia pracodawcy \\
\hline $\mathrm{m}$ & $\begin{array}{l}\text { Beschäftigung einer ambulanten } \\
\text { Pflegekraft }\end{array}$ & $\begin{array}{l}\text { zatrudnienie pielęgniarza/-ki/ } \\
\text { przychodni }\end{array}$ \\
\hline $\mathrm{n}$ & $\begin{array}{l}\text { Bezahlung } \\
\text { Pflegeperson }\end{array}$ & $\begin{array}{l}\text { optacanie obcej osoby sprawujacej } \\
\text { opieke }\end{array}$ \\
\hline
\end{tabular}

Wszystkie niemieckie i polskie jądra nominalne zamieszczone $\mathrm{w}$ powyższej tabeli pochodzą od czasowników rządzących dopełnieniem w bierniku. Po przekształceniu czasowników w substantiva deverbalia dopełnienia $\mathrm{w}$ bierniku (dopełnienia bliższe) obligatoryjnie tworzą przydawki dopełniaczowe, co zresztą jest zgodne $\mathrm{z}$ modelem składniowym Klemensiewicza (1984: 131) oraz Stepanovej/Helbiga (1981: 180). W grupach wyrazowych (a) - (l) oraz (m) i (n) dopełnienie bliższe zostało zamienione na genetivus obiecti, a w syntagmie (l) - na genetivus subiecti.

Jak wynika z powyższych przykładów, rzeczowniki odczasownikowe dziedziczą - w obydwu językach - swoje właściwości konotacyjne od tworzących je wyrazów bazowych, np. etwas vollenden (ukończyć coś) $\Rightarrow$ Vollendung $+G$ (ukończenie czegoś) lub jemanden beschäftigen (zatrudniać/-nić kogoś) $\Rightarrow$ Beschäftigung $+G$ (zatrudnienie kogoś).

Powyższe przykłady świadczą o konotacji obligatoryjnej oraz występowaniu fraz wymaganych (członów obligatoryjnych) w $\mathrm{L}_{1} \mathrm{i} \mathrm{L}_{2}$. Podrzędniki są konotowane i rządzone przez nadrzędnik oraz nieusuwalne (por. Wróbel 2001: 273). Zatem

8 Operacyjnym kryterium stosowanym przy wyznaczaniu granic między członami frazy konotowanymi obligatoryjnie lub fakultatywnie jest $\mathrm{w}$ polszczyźnie test usuwalności zwany transformacją redukującą (por. GWJP 1984: 109). Test polega na stwierdzeniu, czy człony usunięte powodują niepoprawność danej konstrukcji. Topolińska (GWJP 1984: 109) przyjmuje jeszcze kilka dodatkowych warunków stosowania testu usuwalności, jak np. autonomiczność informacyjna, wybór pozycji diagnostycznej, występowanie tego samego znaczenia we frazie niezredukowanej i zredukowanej. 
rzeczowniki derywowane $\mathrm{z}$-ung o znaczeniu procesualnym oraz odpowiadające im w języku polskim rzeczowniki odczasownikowe nazywające określone czynności, tworzone regularnie za pomocą morfemów sufiksalnych -anie, -enie i -cie, dziedziczą wymagania składniowe bazowych leksemów czasownikowych zarówno w polszczyźnie (por. Puzynina 1969), jak i niemczyźnie (por. Ehrich/Rapp 2000).

Tabela 2. Konotacja obligatoryjna przydawki przyimkowej $w L_{1} i L_{2}$

\begin{tabular}{|c|l|lr|}
\hline 2 & $\begin{array}{l}\text { Przydawka przyimkowa } \\
\text { konotowana obligatoryjnie }\end{array}$ & $\begin{array}{l}\text { Przydawka przyimkowa } \\
\text { konotowana obligatoryjnie }\end{array}$ \\
\hline $\mathrm{a}$ & $\begin{array}{l}\text { Kürzung den } \\
\text { Schadenfreiheitsrabatt }\end{array}$ & $\begin{array}{l}\text { pomniejszenie } \\
\text { ubezpieczeniowej o zniżkę za brak } \\
\text { występowania szkód }\end{array}$ \\
\hline $\mathrm{b}$ & Wohnung im Inland & zamieszkiwanie w kraju \\
\hline $\mathrm{c}$ & Beschäftigung am selben Ort & $\begin{array}{l}\text { zatrudnienie w tej samej } \\
\text { miejscowości }\end{array}$ \\
\hline $\mathrm{d}$ & $\begin{array}{l}\text { Entfernung zwischen Wohnung und } \\
\text { Arbeitsstätte }\end{array}$ & $\begin{array}{l}\text { odległość pomiędzy miejscem } \\
\text { zamieszkania a zaktadem pracy }\end{array}$ \\
\hline $\mathrm{e}$ & $\begin{array}{l}\text { Unterbringung zur dauernden Pflege } \\
\text { zakwaterowanie der } \\
\text { sprawowania stałej opieki }\end{array}$ \\
\hline $\mathrm{f}$ & $\begin{array}{l}\text { Weiterversicherung in } \\
\text { gesetzlichen Rentenversicherung }\end{array}$ & $\begin{array}{l}\text { dalsze ubezpieczenie w ustawowym } \\
\text { ubezpieczeniu rentowym }\end{array}$ \\
\hline
\end{tabular}

W tab. nr 2 zebrano przykłady rzeczowników derywowanych w języku niemieckim i polskim, które obligatoryjnie konotują $\mathrm{w}$ podrzędniku frazę wymaganą, a którą tym razem tworzy w obydwu porównywanych językach wyrażenie przyimkowe.

W powyższych grupach przyimki dziedziczone są po czasowniku, np. kürzen um (pomniejszać o) $\Rightarrow$ Kürzung um (pomniejszenie o), lub wskazują na określoną relację nadrzędnika w stosunku do podrzędnika, tj. relację miejsca np. Wohnung in (mieszkanie w), Entfernung zwischen (odległość pomiędzy) lub relację celu, np. Unterbringung zu (zakwaterowanie w celu).

Tabela 3. Konotacja fakultatywna przydawki przyimkowej $w L_{1} i L_{2}$

\begin{tabular}{|c|c|c|}
\hline 3 & $\begin{array}{l}\text { Przydawka przyimkowa } \\
\text { konotowana fakultatywnie }\end{array}$ & $\begin{array}{l}\text { Przydawka przyimkowa } \\
\text { konotowana fakultatywnie }\end{array}$ \\
\hline $\mathrm{a}$ & $\begin{array}{l}\text { Aufwendungen für die befreiende } \\
\text { Lebensversicherung }\end{array}$ & $\begin{array}{l}\text { wydatki na zwalniające (z } \\
\text { ustawowego obowiązku posiadania } \\
\text { ubezpieczenia } \\
\text { ubezpieczenie na życie }\end{array}$ \\
\hline $\mathrm{b}$ & $\begin{array}{l}\text { Bescheinigung über die geleisteten } \\
\text { Beiträge }\end{array}$ & $\begin{array}{l}\text { zaświadczenie } \\
\text { składkach }\end{array}$ \\
\hline $\mathrm{c}$ & Steuerberatungskosten bis 5 & $\begin{array}{l}\text { koszty doradztwa podatkowego do } \\
520 €\end{array}$ \\
\hline $\mathrm{d}$ & $\begin{array}{l}\text { Einkommensteuerveranlagung } \\
2001\end{array}$ & $\begin{array}{l}\text { opodatkowanie podatkiem } \\
\text { dochodowym od osób fizycznych za } \\
2001 \mathrm{r} \text {. }\end{array}$ \\
\hline $\mathrm{e}$ & 2 Euro & zapisy w euro \\
\hline f & Arbeitsvermittlung im Inland & pośrednictu \\
\hline
\end{tabular}


Artur Dariusz Kubacki: Zasady rozbudowywania frazy nominalnej w języku niemieckim i polskim

\begin{tabular}{|l|l|l|}
\hline $\mathrm{g}$ & $\begin{array}{l}\text { Unterhaltsverpflichtung gegenüber } \\
\text { dem Kind }\end{array}$ & $\begin{array}{l}\text { zobowiazania alimentacyjne wobec } \\
\text { dziecka }\end{array}$ \\
\hline $\mathrm{h}$ & $\begin{array}{l}\text { Verdienstausfallentschädigung } \\
\text { nach dem Infektionsschutzgesetz }\end{array}$ & $\begin{array}{l}\text { odszkodowanie z tytułu utraconych } \\
\text { dochodów wg ustawy o ochronie } \\
\text { przeciwinfekcyjnej }\end{array}$ \\
\hline $\mathrm{i}$ & $\begin{array}{l}\text { Sonderunterstützung nach dem } \\
\text { Mutterschutzgesetz }\end{array}$ & $\begin{array}{l}\text { pomoc szczególna wg ustawy o } \\
\text { ochronie macierzyństwa }\end{array}$ \\
\hline
\end{tabular}

Omawiając fenomen konotacji, natrafić można na niemałe trudności związane z tym, które wymagania składniowe są obligatoryjne, a które fakultatywne. Stosując za Topolińską test usuwalności, o którym była już mowa powyżej, można stwierdzić, że w niemieckich i polskich grupach imiennych zebranych w tab. nr 3 przydawki przyimkowe $\mathrm{w}$ podrzędniku sa fakultatywnie konotowane przez nadrzędnik. Dobór przyimka zależy od treści wyrażanej przez frazą przyimkową w $\mathrm{L}_{1} \mathrm{i} \mathrm{L}_{2}$.

Tabela 4. Konotacja fakultatywna $i$ alternatywna przydawki przyimkowej $w L_{1} i$ $L_{2}$

\begin{tabular}{|c|c|c|}
\hline 4 & $\begin{array}{l}\text { ne } \\
\text { tywnie }\end{array}$ & wnie \\
\hline $\mathrm{a}$ & $\begin{array}{l}\text { Erklärung über die Wahl der } \\
\text { Veranlagungsart }\end{array}$ & $\begin{array}{l}\text { oświadczenie o wyborze rodzaju } \\
\text { opodatkowania }\end{array}$ \\
\hline b & $\begin{array}{l}\text { Erklärung zur Feststellung des } \\
\text { verbleibenden Verlustvortrags }\end{array}$ & $\begin{array}{l}\text { oświadczenie } w \text { celu stwierdzenia } \\
\text { pozostatej straty z przeniesienia }\end{array}$ \\
\hline $\mathrm{c}$ & Zuwendungen an politische Parteien & dotacje dla partii politycznych \\
\hline $\mathrm{d}$ & $\begin{array}{l}\text { Zuwendungen für steuerbegünstigte } \\
\text { Zwecke }\end{array}$ & $\begin{array}{l}\text { e na cele zwiazane } \mathrm{z} \text { ulg } \\
\text { cowymi }\end{array}$ \\
\hline $\mathrm{e}$ & Zuwendungen bis $100 €$ & do $100 €$ \\
\hline $\mathrm{f}$ & $\begin{array}{l}\text { Erläuterungen zu den Zeilen } 83 \text { bis } \\
90\end{array}$ & objc \\
\hline$g$ & $\begin{array}{l}\text { Erläuterungen auf der Rückseite der } \\
\text { Anlage } A V\end{array}$ & $\begin{array}{l}\text { objaśnienia } n a \\
\text { załacznika } A V\end{array}$ \\
\hline
\end{tabular}

$\mathrm{W}$ syntagmach nominalnych $\mathrm{z}$ tab. $\mathrm{nr} 4$ mamy przypadki konotacji alternatywnej w rozumieniu Saloniego/Świdzińskiego, a nie Nagórko. W powyższych przykładach nadrzędnik konotuje różne typy wyrażeń przyimkowych tworzących $\mathrm{w}$ tych grupach podrzędniki, przy czym nie dochodzi do zmiany znaczenia konotatora. W powyższych przykładach konotacji alternatywnej nadrzędnik konotuje człony fakultatywne. Są to tylko luźne uzupełnienia. Jedyną trudnością podczas przekładu tego typu fraz jest wyszukanie przyimka oddającego odpowiednią relację semantyczną w odniesieniu do nomina acti. Zazwyczaj są to relacje podobne do tych, jakie wyrażają okoliczniki (Grzegorczykowa 1999: 85).

Reasumując należy stwierdzić, iż - jak uwidaczniają powyższe przykłady rodzaj konotowanych fraz $\mathrm{w}$ podrzędniku w języku niemieckim nie różni się od tych w języku polskim. Są one albo obligatoryjne, albo fakultatywne w obydwu porównywanych językach. Zatem przekład tego typu fraz nie powinien przysparzać żadnych trudności tłumaczowi. To, co może utrudniać dobór odpowiednich translatów, wynika $\mathrm{z}$ rozbieżności między językami w sytuacjach, w których 
tłumacz intuicyjnie spodziewa się zgodności. W rezultacie może dojść do interferencji z języka niemieckiego i użycia w polszczyźnie niepoprawnej rekcji przyimkowej zamiast przypadkowej, np. Verfolgung nach ('ściganie kogoś), Forderung nach (żądanie czegoś) (por. Kubacki 2005: 59).

\subsubsection{Brak zgodności konotowanych fraz $w L_{1} I L_{2}$}

Problem dziedziczenia własności konotacyjnych dotyczy przede wszystkim rzeczowników niemieckich i polskich utworzonych od czasownika, bowiem takie właśnie rzeczowniki przejmują w swoich wariantach wszelkie niuanse struktury znaczeniowej czasowników, a także ich własności konotacyjne. O „całkowitym” dziedziczeniu modelu walencyjnego przez rzeczownik można mówić szczególnie w przypadku takich rzeczowników, które mają wyraźne znaczenie procesualne, tzn. oznaczają czynność lub fakt czynności (nomina actionis) (Niemczuk 1985: 160). W przypadku utraty znaczenia procesualnego rzeczowniki derywowane zmieniają model walencji. Należy wskazać także na wiele przykładów derywatów odczasownikowych, które realizują co najmniej dwa warianty semantyczne, np. procesu i rezultatu. Różnią się one wtedy zarówno znaczeniem, jak i cechami walencyjnymi, np. Beschäftigung (zatrudnienie).

W teorii konotacji zakłada się, że rzeczowniki odczasownikowe z sufiksem ung oraz odpowiadające im polskie rzeczowniki odczasownikowych nazw czynności (nomina actionis) zakończone na -anie, -enie, -cie oraz -acja powinny w sposób regularny przejmować konstrukcje syntaktyczne czasowników będących ich podstawami. Jednak wielu językoznawców (m. in. Schippan 1967, Buttler 1976, Helbig 1976, Niemczuk-Weiss 1992, Erich/Rapp 2000) wskazuje na „zaburzenia” w dziedziczeniu przez te rzeczowniki modelu łączliwości. We wszystkich przypadkach chodzi o przeobrażenia semantyczno-syntaktyczne wpływające na walencję rzeczowników odczasownikowych.

Wśród wszystkich fraz nominalnych występujących w analizowanym korpusie zawierających derywaty $\mathrm{z}$-ung oznaczające nomina actionis znaleziono zaledwie kilka przykładów, które różnią się właściwościami konotacyjnymi rzeczowników w $\mathrm{L}_{1}$ i $\mathrm{L}_{2}$. Różnice dotyczą głównie ilości aktantów obligatoryjnych (tab. 5) oraz rodzaju uzupełnień obligatoryjnych (tab. 6) pomiędzy językiem niemieckim a polskim.

Tabela 5. Konotacja obligatoryjna różnej ilości aktantów $w L_{1} i L_{2}$

\begin{tabular}{|c|c|c|}
\hline 5 & $\begin{array}{l}\text { Rzeczownik konotujący } \\
\text { zero lub jeden argument }\end{array}$ & $\begin{array}{l}\text { Rzeczownik konotujący } \\
\text { jeden lub dwa argumenty }\end{array}$ \\
\hline $\mathrm{a}$ & $\begin{array}{l}\text { Freistellungsbescheinigung } \\
\text { des Finanzamts }\end{array}$ & $\begin{array}{l}\text { zaświadczenie z urzędu skarbowego } \\
\text { o zwolnieniu } \text { z opodatkowania } \\
\text { (SPiK) }\end{array}$ \\
\hline $\mathrm{b}$ & Überweisung des Erstattungsbetrags & przelanie kwoty zwrotu podatku \\
\hline $\mathrm{c}$ & Bestimmung der Werbungskosten & $\begin{array}{l}\text { określenie kosztów uzyskania } \\
\text { przychodu (SPiK) }\end{array}$ \\
\hline $\mathrm{d}$ & $\begin{array}{l}\text { Freistellung der ausländischen } \\
\text { Einkünfte }\end{array}$ & $\begin{array}{l}\text { zwolnienie dochodów zagranicznych } \\
\text { z opodatkowania (LEXIKON) }\end{array}$ \\
\hline $\mathrm{e}$ & $\begin{array}{l}\text { Kürzung um } \\
\text { Schadenfreiheitsrabatt }\end{array}$ & $\begin{array}{l}\text { pomniejszenie } \\
\text { ubezpieczeniowej o zniżkę za brak } \\
\text { wystepowania szkód }\end{array}$ \\
\hline
\end{tabular}




\section{Artur Dariusz Kubacki: Zasady rozbudowywania frazy nominalnej w języku niemieckim i polskim}

W pierwszych trzech przykładach rzeczowniki Freistellung, Erstattung i Werbung konotują zero argumentów, zaś ich polskie odpowiedniki posiadają jeden argument obligatoryjny. W kolejnych dwóch przykładach rzeczownik $\mathrm{z}$-ung konotuje jeden argument, zaś jego polski odpowiednik konotuje dwa argumenty.

W (a) przydawka dopełniaczowa przy czasowniku pełniła funkcję podmiotu. W przykładach (b) - (d) w podrzędniku pojawia się przydawka dopełniaczowa na skutek przekształcenia bliższego dopełnienia biernikowego. W ostatnim przykładzie podrzędnik tworzy niezmienione wyrażenie przyimkowe dziedziczone od czasownika.

Członami konotowanymi obligatoryjnie w polszczyźnie są dodatkowe elementy w podrzędniku, których nie ma w strukturach wyjściowych, tj. w (a) i (d) konstrukcja przyimkowa $z$ opodatkowania, natomiast w (b) i (c) jest to rzeczownik w dopełniaczu - podatek i przychód. W (e) sytuacja wygląda nieco inaczej. Rzeczownik odczasownikowy Kürzung (pomniejszenie) musi konotować w niemczyźnie i polszczý́nie takie aktanty, jakie ma czasownik bazowy, który jest trójaktantowy: ktoś pomniejsza coś o coś. Ponieważ określenie agensa przy rzeczowniku odczasownikowym - jak uważają autorzy słownika walencji rzeczowników niemieckich Sommerfeld/Schreiber (1977: 33) - nie jest obligatoryjne (odwrotnie niż w przypadku czasownika), rzeczownik odsłowny Kürzung (pomniejszenie) musi mieć zatem dwa aktanty, tj. pomniejszenie czegoś o coś. $\mathrm{Z}$ analizowanego przykładu wynika, że genetivus obiecti został wyzerowany we frazie niemieckiej, natomiast jego obecność we frazie polskiej jest niezbędna. Dlatego translat został uzupełniony o człon obligatoryjny rzeczownika derywowanego skladka ubezpieczeniowa.

Tabela 6. Konotacja obligatoryjna aktantów należących do różnych kategorii gramatycznych $w L_{1} i L_{2}$

\begin{tabular}{|c|c|c|}
\hline \multirow[t]{2}{*}{6} & \multirow{2}{*}{$\begin{array}{l}\mathrm{NP}_{\mathrm{GEN}} \\
\text { Romut7umg }\end{array}$} & \multirow{2}{*}{$\begin{array}{l}\text { Rzeczownik konotujący } \quad \text { w } \\
\text { podrzędniku argument w postaci: } \\
\text { NPPRÄP lub NPINSTR }\end{array}$} \\
\hline & & \\
\hline $\mathrm{a}$ & $\begin{array}{l}\text { Benutzung } \\
\text { Verkehrsmittel }\end{array}$ & $\begin{array}{l}\text { korzystanie z publicznych środków } \\
\text { lokomocji }\end{array}$ \\
\hline b & $\begin{array}{l}\text { Bescheinigung } \\
\text { Wohnsitzgemeinde } \\
\text { des Kindes }\end{array}$ & $\begin{array}{l}\text { zaświadczenie z gminy } \\
\text { zamieszkania dziecka }\end{array}$ \\
\hline $\mathrm{c}$ & $\begin{array}{l}\text { Betreuung eines zum } \\
\text { gehörenden Kindes }\end{array}$ & do $\begin{array}{rr}\text { się } & \text { dzieckiem } \\
& \text { gospodarstwa }\end{array}$ \\
\hline
\end{tabular}

W tab. nr 6 mamy - w języku niemieckim - przypadki konotacji obligatoryjnej przydawki dopełniaczowej w (a) - (c). W języku polskim rzeczowniki odczasownikowe konotują inny rodzaj przydawki. W odróżnieniu od $\mathrm{L}_{1} \mathrm{w}$ podrzędniku polskim w (a) mamy przydawkę przyimkową dziedziczoną wskutek rekcji czasownika korzystać $z \Rightarrow$ korzystanie $z$. W (b) zaświadczenie nie ma rekcji kazualnej jak w języku niemieckim, lecz wykładnik analityczny, tj. przyimek $z$. W (c) rzeczownik odsłowny opiekowanie sie (kim? czym?) dziedziczy rekcję przypadkową po czasowniku opiekować się (kim? czym?), tj. narzędnik, dlatego rzeczownik wymaga również użycia narzędnika. Jeśli nastąpi zmiana rzeczownika 
procesualnego opiekowanie się na rzeczownik stanu opieka (nomina acti), wówczas także zmienią się właściwości konotacyjne rzeczownika. Zamiast oczekiwanej grupy narzędnikowej w podrzędniku trzeba będzie utworzyć wyrażenie przyimkowe (opieka nad kimś lub czymś).

Jak pokazują przykłady z korpusu, znajomość właściwości konotacyjnych rzeczowników niemieckich i polskich może być pomocna przy tłumaczeniu grup nominalnych z jednego języka na drugi.

\section{Wnioski}

Podsumowując rozważania dotyczące rozbudowywania grupy nominalnej w języku niemieckim i polskim, należy wskazać na kilka podobieństw i różnic $\mathrm{w}$ tym zakresie.

Fenomen wieloczłonowości przydawek, zarówno przymiotnych, jak i rzeczownikowych i przyimkowych, znany jest w obydwu językach. Przydawki te można przyłączać na zasadzie para- lub hipotaksy. Pierwszą różnicą w odniesieniu do przydawek wieloczłonowych jest ścisły szyk wyrazów w niemieckiej przydawce lewostronnej, która tworzy ramę nominalną. W polszczyźnie szyk ten jest swobodniejszy. Drugą różnicą jest fakt, że przymiotniki i imiesłowy przymiotnikowe wraz $\mathrm{z}$ ich określeniami mogą występować w niemczyźnie tylko po lewej stronie nadrzędnika, zaś w polszczyźnie mogą także pojawić się po prawej stronie.

Ponadto $\mathrm{w}$ języku niemieckim przydawkami są podrzędniki rzeczowników, przymiotników i przysłówków. Natomiast w polszczyźnie przydawkami są tylko podrzędniki rzeczowników.

Sposób rozwijania frazy nominalnej w języku niemieckim i polskim wg zasad składniowych jest praktycznie taki sam. Rzeczowniki niemieckie przyjmują maksymalnie do trzech, a rzeczowniki polskie do pięciu argumentów. Konotują one frazy obligatoryjne i/lub fakultatywne. Odróżnia je czasami inna konstrukcja gramatyczna argumentów. Mimo dużego podobieństwa między właściwościami konotacyjnymi (walencyjnymi) czasowników i rzeczowników odczasownikowych można stwierdzić przypadki nieregularnego dziedziczenia konstrukcji syntaktycznych przez rzeczowniki odczasownikowe w języku niemieckim i polskim.

Jak wynika z korpusu, odmienność konotacyjna derywatów z -ung i ich polskich ekwiwalentów z rzadka może być źródłem powstania nieadekwatnego translatu. Dzieje się tak dlatego, że zdecydowana większość polskich ekwiwalentów derywatów z -ung ma identyczne właściwości konotacyjne. Różnice pojawiają się w zaledwie kilku przypadkach. Polegają one albo na innej liczbie aktantów, albo na innej składni rządu. Nieuwzględnienie różnic konotacyjnych może spowodować powstanie niegramatycznej lub nieścisłej znaczeniowo konstrukcji.

\section{Bibliografia}

Bühler, K. 1934. Sprachtheorie. Jena: Verlag von Gustav Fischer.

Bußmann, H. 1990. Lexikon der Sprachwissenschaft. Stuttgart: Kröner.

Buttler, D. 1976. Innowacje składniowe wspótczesnej polszczyzny. (Walencja wyrazów). Warszawa: PWN.

Dębski, A. 1987. Zum Valenzbegriff in der polnischen Linguistik. w: Zeitschrift für Germanistik 8, s. 709-719.

Engel, U. 1988. Deutsche Grammatik. Heidelberg: Julius Groos Verlag. 

niemieckim i polskim

Erich, V., Rapp I. 2000. Sortale Bedeutung und Argumentstruktur: -ungNominalisierungen im Deutschen. w: Zeitschrift für Sprachwissenschaft 19.2, Göttingen, s. 245-303.

Eroms, H.-W. 2000. Syntax der deutschen Sprache. Berlin/New York: de Gruyter.

Golonka, J. 2002. 'Thre Meinung dazu' oder: 'Wie denken Sie darüber?' Zur Vererbung verbaler Valenzmerkmale in Nominalphrasen des Deutschen und des Polnischen. Eine Studie am Beispiel ausgewählter Verben und Verbalnomina des Denkens und des Urteilens. Mannheim: Institut für Deutsche Sprache.

Grzegorczykowa, R. 1999. Wykłady z polskiej składni. Warszawa: PWN.

Helbig, G. 1976. Valenz, Semantik, Satzmodelle. w: DaF 13, Leipzig, s. 99-106.

Helbig, G., Buscha, J. 1984. Deutsche Grammatik. Ein Handbuch für den Ausländerunterricht. Leipzig: VEB Enzyklopädie.

Helbig, G., Schenkel, W. 1969. Wörterbuch zur Valenz und Distribution deutscher Verben. Leipzig: VEB Bibliographisches Institut.

Jodłowski, S. 1977. Podstawy polskiej składni. Warszawa: PWN.

Klemensiewicz, Z. 1984. Podstawowe wiadomości z gramatyki języka polskiego. Warszawa: PWN.

Kubacki, A. D. 2005. Strategie tłumaczenia derywatów $\mathrm{z}$-ung na przykładzie tekstu prawniczo-ekonomicznego. w: Lingua Legis 13, Warszawa, s. 58-67.

Milewski, T. 1965. Językoznawstwo. Warszawa: PWN.

Morciniec, N., Cirko, L., Ziobro, R. 1995. Wörterbuch zur Valenz deutscher und polnischer Verben. Wrocław: Wydwnictwo Uniwersytetu Wrocławskiego.

Nagórko, A. 2003. Zarys gramatyki polskiej. Warszawa: PWN.

Niemczuk, E. 1985. Walencja rzeczowników odczasownikowych o formantach -anie, -enie, -cie a ich związki semantyczne z czasownikiem. w: A. Bartoszewicz, A. Szyrokowa (red.): Badania nad czasownikiem $w$ językach stowiańskich. Warszawa: Wydawnictwo Uniwersytetu Warszawskiego, s. 155-169.

Niemczuk-Weiss, E. 1992. Rzeczowniki niemotywowane o własnościach walencyjnych (próba podziału). w: A. Markowski (red.): Opisać stowa. Warszawa: Wydawnictwo Uniwersytetu Warszawskiego, s. 106-117.

Polański, K. (red.) 1980-1992. Stownik syntaktyczno-generatywny czasowników polskich. Wrocław: Ossolineum.

Puzynina, J. 1969. Nazwy czynności we współczesnym języku polskim. Warszawa: PWN.

Saloni, Z., Świdziński, M. 2001. Składnia współczesnego języka polskiego. Warszawa: PWN.

Schatte, Ch. 1981. Zum nominalen Attribut im Deutschen und Polnischen. w: Studien zum polnisch-deutschen Sprachvergleich 1, Kraków, s. 77-91.

Schenkel, W. 1972. Zur erweiterten Attribuierung im Deutschen. Halle (Saale): Niemeyer.

Schippan, T. 1967. Die Verbalsubstantive der deutschen Sprache der Gegenwart. Leipzig: Universität Leipzig.

Sommerfeld, K.-E., Schreiber, H. 1977. Wörterbuch zur Valenz und Distribution der Substative. Leipzig: VEB Bibliographisches Institut.

Sommerfeld, K.-E., Schreiber, H. 1983. Wörterbuch zur Valenz und Distribution deutscher Adjektive. Leipzig: VEB Bibliographisches Institut.

Stepanova, M. D., Helbig, G. 1981. Wortarten und das Problem der Valenz in der deutschen Gegenwartssprache. Leipzig: VEB Bibliographisches Institut.

Strutyński, J. 2002. Gramatyka polska. Kraków: Wydawnictwo Tomasz Strutyński.

Tesnière, L. 1966. Eléments de syntaxe structurale. Paris: Klincksieck.

Toman, J. 1983. Wortsyntax. Eine Diskussion ausgewählter Probleme deutscher Wortbildung. Tübingen: Niemeyer.

Weinrich, H. 1993. Textgrammatik der deutschen Sprache. Mannheim: Duden.

Wróbel, H. 2001. Gramatyka języka polskiego. Kraków: Wydawnictwo „Od Nowa” s.c. 
Zaron, Z. 1988 Niektóre problemy z konotacją syntaktyczną. w: J. Bartmiński (red.): Konotacja. Lublin: Wydawnictwo UMCS, s. 113-119.

\section{Wykaz skrótów}

EJO Polański, K. (red.) 1999. Encyklopedia językoznawstwa ogólnego. Wrocław: Ossolineum.

GWJP Topolińska, Z. (red.) 1984. Gramatyka wspótczesnego języka polskiego. Sktadnia. Warszawa: PWN.

LEXIKON Lexikon: Fachwörter für die Steuerberatung. Deutsch-Polnisch. Rechnungswesen, Steuerrecht, Handelsrecht. Kraków/Nürnberg: Forum Doradców Podatkowych/Datev, 2000.

SPiK Marciszewski, M., Milewski, P. 2000. Niemiecko-polski, polsko-niemiecki stownik podatków i księgowości. Warszawa: Difin. 